\title{
Assessment of groundwater potential zone for sustainable water resource management in south-western part of Birbhum District, West Bengal
}

\author{
Soumen Chatterjee ${ }^{1}$ (1) $\cdot$ Shyamal Dutta ${ }^{1}$
}

Received: 7 June 2021 / Accepted: 23 November 2021 / Published online: 11 February 2022

(c) The Author(s) 2022

\begin{abstract}
Water is an indispensable natural resource for survival of any species in the globe. For centuries, civilization has flourished on the bank of river based on the easy availability of water. Groundwater is one of the prime sources of freshwater supply, but, its occurrence and spatial distribution are highly uneven and affected by several surface and subsurface features. Development of several geospatial tool based on the remote sensing and GIS in recent time helps immensely for delineation and management of this precious resource. The present study has been undertaken in south-western part of Birbhum district, West Bengal with an objective to delineate groundwater potential zone using multiple criteria decision analysis and GIS. Seven thematic layers concerning with geology, geomorphology, hydrology, land use land cover and edhaphic factor have been employed in this study with proper weightage depending on their role in groundwater formation to identify the groundwater potential zone. By using analytical hierarchy process, whole study area has been classified into four zones ranging from excellent to poor. Primary field data and secondary data about depth of groundwater have been compared with the result to make it authentic. The result shows that the southern part composed of alluvial plain has the excellent potential compared to the northern lateritic and pediment part where groundwater potential is moderate. Eventually, few recommendation and suggestion have been framed for sustainable water resource management that will help the researchers, planners and other decision-makers for judicious exploration and management of the groundwater resource in the study area.
\end{abstract}

Keywords Groundwater potential zone $\cdot$ Multiple criteria decision-making $\cdot$ Water resource management $\cdot$ Remote sensing and GIS · Hydro-geomorphology

\section{Introduction}

Groundwater is considered to be the chief source of freshwater that satisfies the demands for water in different sectors like agriculture, domestic, industrial and other (Agarwal et al. 2013, Das et al. 2018). According to an estimate, $34 \%$ of annual freshwater demand has been satisfied by the groundwater (Magesh et al. 2012). Besides that, the supply of groundwater was found to be the least affected by drought events and has greater yield capability than the surface water (Biswas et al. 2012). Das (2017) considered groundwater as

Soumen Chatterjee

chatterje.soumen@gmail.com

Shyamal Dutta

duttashyamal1987@gmail.com

1 Durgapur, West Bengal, India the most dynamic natural resource which has an active role in maintaining ecological system. Since last few decades, the demands of groundwater have increased steadily in all sectors, as a result, an acute and long-term crisis has been arising in the availability of this resource (Das et al. 2018). In many cases, the supply of groundwater has not been able to meet the demand of the society (Mukherjee et al. 2012). Use of water resource in an unscientific way coupled with incorrect management makes the problem more severe especially in the developing countries (Thapa et al. 2017). Several scholars acknowledged that the demand for water resource, especially in the developing world, is increasing at an alarming pace (Black and Talbot 2005; Holden 2014). Central Ground Water Board (2014) has reported that almost $90 \%$ of water need for domestic purpose in rural areas has been met by groundwater. The report has also mentioned that almost half of irrigated water and a similar proportion of urban industrial water have been supplied from this source. 
However, the groundwater considered to be finite resource whose spatial distribution is not even and its formation has been controlled by several factors (Chowdhury et al. 2009; Thapa et al. 2017; Ganapuram et al. 2009). Formation and availability of groundwater in any region were found to be controlled by several factors. Important among them are physiography, subterranean lithological composition, depth of weathering, drainage pattern, land use land cover, climatic condition, edhaphic factors, geological structural include presence or absence of fracture and lineaments, etc. (Sar et al.2015; Aladejana et al.2016; Deepa et al. 2016; Dasho et al. 2017). Judicious utilization of groundwater and its conservation depend to a great extent on the identification and delineation of the groundwater potential zone (Hutti and Nijagunappa 2011). Most of the previous studies have used traditional techniques related to geology, hydro-geology, geophysics and photo geology for the demarcation of groundwater potential zone (McNeill 1991; Meijerink 1996; Sander et al. 1996; Srivastava and Bhattacharya 2006). For decades, these techniques have provided useful information and are used widely for the preparation of potential zone. However, compared with the recent technological advancement, these techniques are proven to be very labourious and time consuming. Moreover, development in the RS and GIS technology and availability of high-resolution satellite image had ease the process of delineation to a great extent (Chenini et al. 2010; Machiwal et al. 2011). Multicriteria decision analysis process (MCDA), in recent time, is popular and widely accepted method used for any kind of geospatial analysis including management of groundwater resource (Madrucci et al. 2008; Jha et al. 2010; Rahmatiet al. 2015). Analytic hierarchy process (AHP) is one of the common method of MCDA process where total data set has been arranged in a hierarchical order and each set has been given a relative importance depending on its significance in the decision-making process proposed by Saaty (1980, 1999). This method has the opportunity to consider a number of parameter that has various extents of influences in the achievement of a goal (Chowdhury et al. 2009; Kaliraj et al. 2014). The process started with the identification of well-defined parameter associated with the process (Das N et al. 2018). The next step is associated with the preparation of pairwise comparison matrix with assigning of proper relative importance (Saaty 1980). Finally, weight has been assigned to each thematic layer following the ratio matrix (Jha et al. 2010; Adiat et al. 2012). Groundwater prospect zone has been delineated from the consistency index from the ration matrix (Saaty 1980).

This study has been conducted on the Dubrajpur CD block of Birbhum district. The study area is located on the south-western part of the district sharing common boundary with the block of Khoyrasol, Rajnagar and Illambazar in the west north and east, respectively. The mighty river Ajay is located on the southern part of the study area. Geologically, most of the study area comprised of hard terrain with granitic gneissic rock. Climatically, the area is under the influence of tropical monsoonal climate with alternative wet and dry season. The late summer marked the onset of monsoon when the study area experiences plenty of rainfall succeeded by dry spell of winter when the region received no rain. All these factors are responsible for high fluctuation of groundwater table that causes scarcity in the supply of both domestic and agricultural supply of water (Nag et al. 2015). Majority of the people in the study area earn their livelihood from agriculture. Erratic nature of monsoon sometime attributed lower rainfall that also causes paucity in the supply of water. Shortage in the supply for prolonged time invariably causes crop failure and drought situation. In such situation, there has no way but to rely on the exploitation of groundwater. Indiscriminate exploitation of groundwater in some parts of the district has reported a number case where groundwater is found to be contaminated with fluoride in recent time (Mondal et al. 2014, Thapa et al. 2017). Undoubtedly, the situation is a matter of serious concern that may lead to a environmental degradation. In this study, an attempt has been made to delineate potential groundwater zone in the south-western part of Birbhum district using geospatial tool for sustainable utilization of groundwater resources.

\section{Methods and database}

\section{Study area}

Physiographically, the District of Birbhum is a part of the primordial Rarh region in the Eastern India (Bagchi et al. 1983). The south-western segment of this district is fundamentally an annexe of the Chotanagpur Plateau and Dubrajpur Block is component of the Suri-Bolpur Plain among the four sub-micro-physiographic regions of whole district. The area under study covers the latitudinal extension of $23^{\circ}$ $41^{\prime} 23^{\prime \prime} \mathrm{N}$ to $23^{\circ} 54^{\prime} 48^{\prime \prime} \mathrm{N}$ and longitudinal extension of $87^{\circ}$ $18^{\prime} 18^{\prime \prime} \mathrm{E}$ to $87^{\circ} 31^{\prime} 08^{\prime \prime} \mathrm{E}$ with a geographical area of 344.88 sq km which contains $10 \mathrm{~g}$ Panchayat units and 226 rural mouzas (Fig. 1). From drainage perspective, this region is in the interfluves of the River Mayurakshi and Ajay which exhibits to some extent upland topography inclined from northwest to south-east direction and an extension upto the adjacent Bakreshwar Uplands (Das and Mukhopadhyay 2018; Census of India 2011). This highland of the western part of the district is positioned on the hard, impervious crystalline rocks of Archaean era. Soil of the region is red and yellow with occasional patches of laterite and alluvium. From Agro-climatic and ecological classification outlook, the study area is under Eastern Plateau and Hill region with sub-humid dry climatic regime containing annual average 


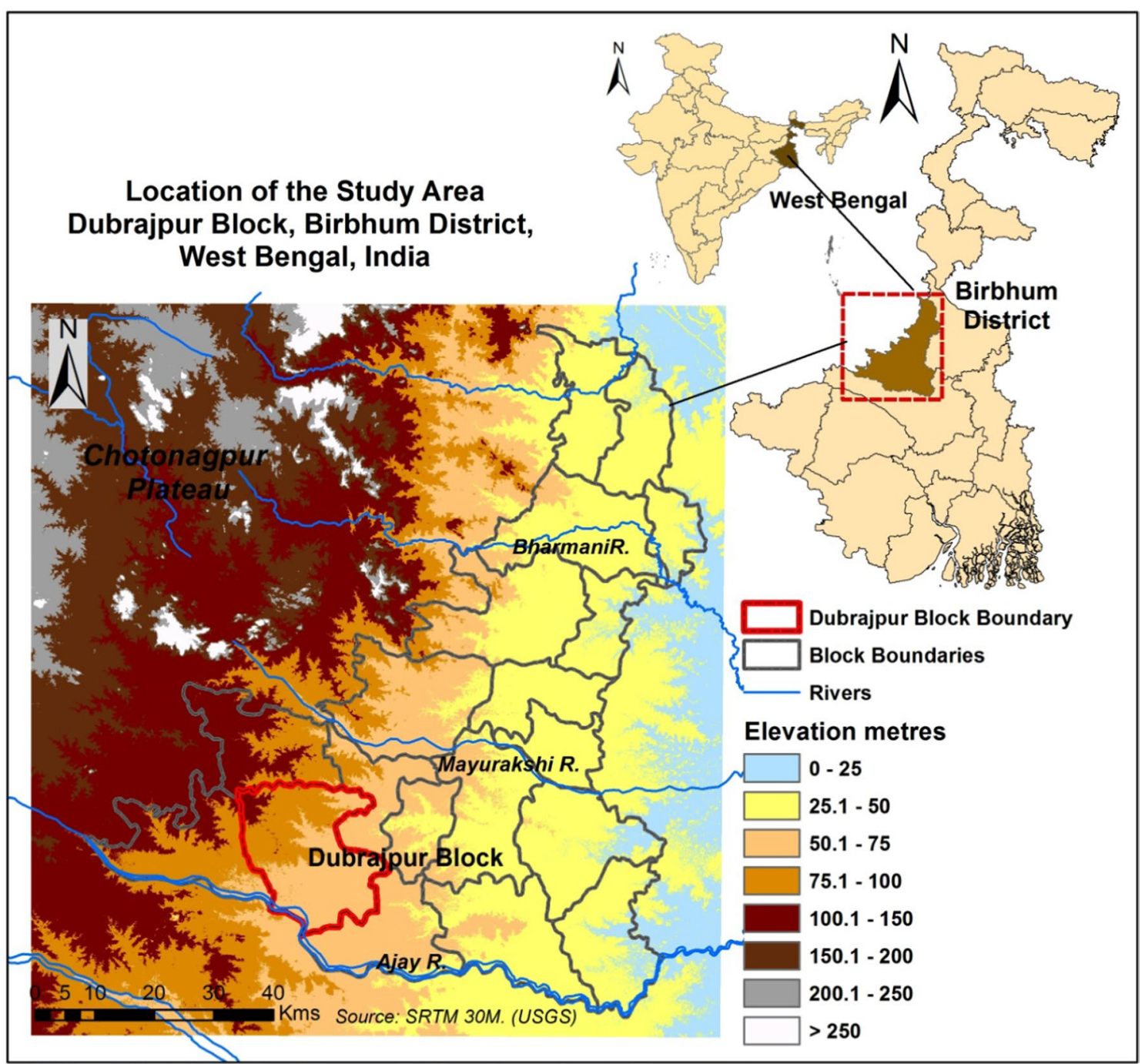

Fig. 1 Location of the Study Area

temperature of $10-27{ }^{\circ} \mathrm{C}$ in the month of January and $26-34{ }^{\circ} \mathrm{C}$ in the month of July with annual average rainfall of $80-150 \mathrm{~cm}$ (http//:cgwb.gov.in). Average aquifer level of this block is within $140 \mathrm{~m} \mathrm{BGL}$ where proposed depth of tube well is $150 \mathrm{~m}$ BGL (CGWB 2020). Major economy of this block is commonly based on agriculture and field-based activities; where $75 \%$ to total folk are engaged in agricultural activities. As a result, there is massive requirement of groundwater for the irrigation purpose which results in dwindling level of the subsurface water resources day by day. Main crops produced within the average growing period of 15 to 180 day are rice, millets, maize, gram and potatoes.

\section{Database and method}

The present study intended to examine the groundwater potential zone of Dubrajpur block by using both statistical and geospatial tool which can be useful for the sustainable groundwater management. To understand the major determinants of groundwater several physiographic, subsurface (geology) and surface characteristics (LULC) and edaphic condition have been examined in the GIS environment. Such factors then assign proper weightage using Analytic Hierarchy Process Method (AHP). This method is quite popular and effective method of multi-criteria decision-making process (Saaty 1980). Once the proper weight of each class has been determined, an overlay analysis has been performed using raster calculator in QGIS software. The resultant output indicates the potential zone. The whole process may be described as follows (Fig. 2). 


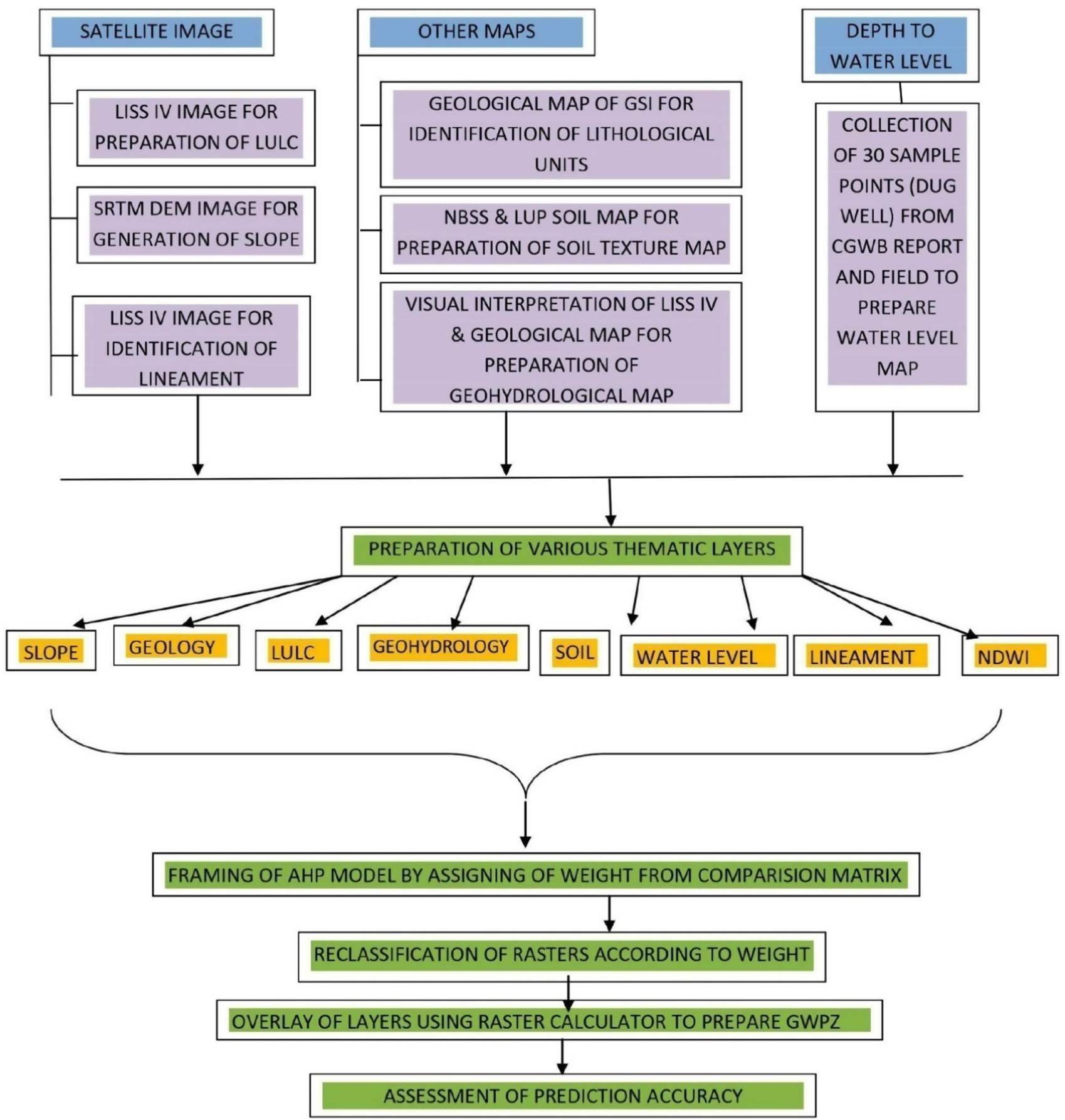

Fig. 2 Methodological framework of the study

\section{Preparation of geospatial database}

As mentioned earlier, this study employed seven factors that are likely to affect the formation and distribution of groundwater which are hydro-geomorphologic units, slope, geology, land use land cover, depth to water level, lineament density and soil texture. Each of the factors is considered to have a different extent of influence on the production and storage of groundwater on the one hand and acts as reliable source to demarcate potential groundwater zone (Rahmati et al. 2015; Jhariya et al. 2016).

Subsurface geology of any area has strong control over the storage and availability of groundwater. Various lithological units of the study area have been extracted from the quadrangle map no 73M prepared by Geological Survey of India (GSI). They are considered to affect the porosity and 
movement of groundwater (Jhariya et al. 2016). The area is chiefly composed of Chhotonagpur granitic gneissic complex which have the least groundwater potential, and the rivirine alluvial plain has the maximum groundwater potentials. Hence, the former lithological unit has been given least weight compared to the later.

To understand the surface features slope, LULC, geomorphic units and lineament density have been considered. 30-meter SRTM digital elevation data have been used to generate slope map of the study area. Groundwater recharge and formation were found to be affected by the nature of slope. IRS P6-LISS IV data and SOI Topographical map $(73 \mathrm{M} / 5$ and $73 \mathrm{M} / 6)$ have been used to classify the land use land cover information. IRS P6 satellite has been launched by Indian Space research Organization which is alternatively known as Resourcesat. It has a spatial resolution of 5.8 meter. The image possesses the path and row number of 107 and 55, respectively. The image is acquired on February 13, 2014. Supervised image classification using maximum likelihood algorithm has been applied to the image to generate the LULC of the study area. Several LULC was found to be affecting the infiltration rate and formation of groundwater. Lineaments are the linear to curvilinear features generated by the crustal movement. It influences the infiltration rate thereby groundwater recharge has been influenced by the presence of lineaments (Haridas et al. 1998; Magesh et al. 2012). IRS P6-LISS IV satellite data along with the geological map have been employed to extract the lineament of the study area. Anomaly in the tone, texture, pattern and association of features has been studied for identification of lineaments. Generally, the presence of lineaments affects the drainage pattern; hence, drainage line has been examined thoroughly to extract lineaments. Geological setup and soil character of the study area have also been examined to identify the lineaments. They strongly control the infiltration and the recharge of groundwater in any region. So, area with higher lineament density has been given greater weight compared with the area with lesser density. Similarly, hydrogeomorphic units have been identified using the same image. They determine porosity and the movement of groundwater (Ayazi et al. 2010; Chowdhury et al. 2010).

Soil texture is an important edhaphic parameter for delineation of groundwater potential zone which controls the percolation rate and recharge of groundwater (Das et al. 2018). The soil texture map of the study area has been prepared following the soil map of West Bengal prepared by NBSS and LUP. Here, description of each soil class along with their taxonomic name and moisture condition are available. Specific soil class of the study area has been extracted from this map to delineate soil textural class which is later verified with the soil texture map available in the Birbhum district portal. Loamy soil is having the higher rate of infiltration assigned with greater weight compared to the skeletal soil of the study area. Finally, the pre-monsoon and post-monsoon and water level data for 30 dug well have been collected from the Central Ground Water Board (CGWB: http://cgwb. gov.in/ GW-data-access.html). Spatial interpolation has been performed using kriging method which is the widely applied geo-statistical tool that can minimize the error of prediction. Distribution of surface water body seems to have great control over groundwater recharge, hence, influencing the groundwater availability in any area. The distribution of surface water body has been taken into account in the present study. Water bodies generally have low reflectance. The NIR and SWIR bad of Landsat 7 have been employed to extract the surface water body in the form of normalized difference water index (NDWI) using the equation proposed by Gao (1996). Logically higher the existence of surface water body, greater will be the possibility to hold more water and infiltration rate. So, greater value has been assigned to the area with high positive NDWI value.

\section{Formulation of AHP model}

AHP is a simple and famous multi-criteria decision-making process which is used to weight criteria. In this study, seven criteria have been selected to calculate the potential groundwater zone. Each criterion has five alternatives where the lowest value indicates poor status and the highest value indicates the good one. So the AHP model has been organized in a hierarchical model where the Goal has been kept in the first level criteria forms the second level and the alternatives composed the third level.

a. Formation of pairwise comparison matrix:

It represents the relative importance of various attributes with respect to the fulfillment of goal. The matrix has been created using scale of relative importance on the basis of Saaty's 1-9 scale (Saaty 1980). Here, 1 represents equally important, whereas 9 represents extremely important. Considering the groundwater prospect, poor to very good linear ranking has been assigned where 1 represents poor status, while 5 represents very good potential.

b. Normalized pairwise matrix:

It has been used to calculate the criteria weight. All the elements of the column are divided by the sum of the column to create the normalized pairwise matrix. Thereafter by averaging all the elements of the row and 

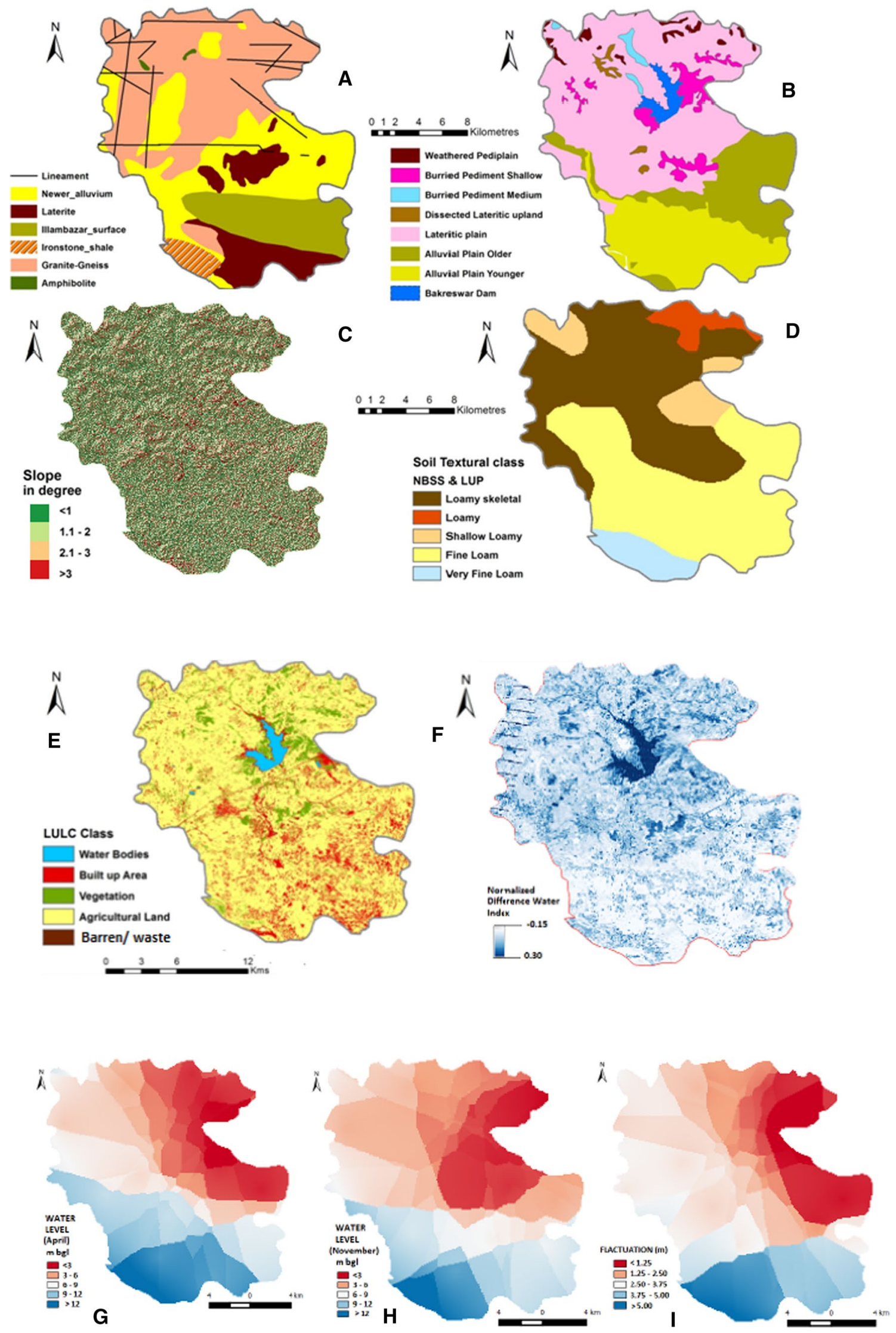
4Fig. 3 Thematic layers of different variables: A Geological Framework with Lineament, B Hydro-geomorphology, C Slope, D Soil Texture E Land Use Land Cover, F Normalized Difference Water Index map. Depth of Groundwater: G Pre-monsoon, H Post-Monsoon, I Groundwater Level Fluctuation

dividing it with the number of criteria, weight has been obtained.

c. Consistency index:

To check how far the calculated value represents the reality, consistency ratio has been calculated. Pairwise comparison matrix has been multiplied by the criteria value. Thereafter, sum of the row represents weighted sum value. Eigen value or the priority vector $\left(\lambda_{\max }\right)$ has been calculated by making the ratio between these two and averaging it with the number of criteria (Jha et al. 2010; Adiat et al. 2012).

$\lambda \max =\frac{C 1+C 2 \ldots . . C n}{n}$

where $C 1$ to $C$ n represent weighted sum value and $\mathrm{n}$ is the number of criteria.

Thereafter, consistency index (CI) has been computed by the following formula:

$\mathrm{CI}=\frac{\lambda \max -n}{n-1}$

Finally, we calculate consistency ratio $(\mathrm{CR})$ by the following formula:

$\mathrm{CR}=\frac{\mathrm{CI}}{\mathrm{RI}}$

$\mathrm{RI}$ is the consistency index of randomly generated pairwise matrix.

\section{Delineation of potential zone}

Eventually, weighted linear combination (WLC) technique has been employed to delineate the groundwater potential zones using following formula (Jha et al. 2010; Agarwal et al. 2013; Shekhar and Pandey 2014).

$$
\begin{aligned}
\mathrm{GWP}= & \mathrm{HG}_{w} \mathrm{HG}_{\mathrm{wi}}+\mathrm{Sl}_{w} \mathrm{Sl}_{\mathrm{wi}}+\mathrm{G}_{w} \mathrm{G}_{\mathrm{wi}} \\
& +\mathrm{Lu}_{w} \mathrm{Lu}_{\mathrm{wi}}+\mathrm{DW}_{w} \mathrm{DW}_{\mathrm{wi}} \\
& +\mathrm{L}_{w} \mathrm{~L}_{\mathrm{wi}}+\mathrm{S}_{w} \mathrm{~S}_{\mathrm{wi}}
\end{aligned}
$$

where $\mathrm{W}$ represents normalized weight of each thematic layer and Wi stands for normalized weight of the features. $\mathrm{HG}=$ hydrogeomorphology; $\mathrm{Sl}=$ slope; $\mathrm{Lu}=$ land use/land cover; $\mathrm{L}=$ lineament density; $\mathrm{S}=$ soil texture and DW represents fluctuation.

\section{Validation of the model}

In order to cross-check the resultant groundwater potential zone, 30 actual borehole-yield data have been collected and the results have been cross-checked. They are presented in Table 4. It has been found that out of 30 data 22 has been tallied with the resultant groundwater potential zone. So there has been $73.33 \%$ accuracy found in the resultant data that indicate present study yields significant reliable result.

\section{Formulation of management proposal}

Owing to certain constrain in the availability of groundwater that can be inferred from the potential zone, it is now customary to formulate some management plan which is considered being indispensible for sustainable water resource management. Hence, some proposal based on the surface and subsurface features that employed in the study has been attempted.

\section{Results}

\section{Spatial outlook of different variables}

In order to explain the potentiality of groundwater in the area under study, a number of layer specific maps have been organized from SOI topographical maps, remotely sensed Satellite images, geological map and other available data. The spatial outlooks as the inputs namely geological structure, occurrence of lineament, slope, hydrogeomorphology, spatial mosaic of land use land cover, distribution of soil texture, water index and depth to seasonwise subsurface water level have been incorporated for the demarcation of groundwater potential zones.

\section{Geological framework}

From the analysis of geological output and stratigraphic chronology of the whole district as elaborated by Mukherjee et al. (1969), it is clear that the Archaean rocks are largely uncovered in the south-western part, whereas the Gondwanas are set up as uneven patches in the south, as well as south-western frank along the Ajay River (CGWB 2009). The. study area comprises six major lithological formations under three geological periods of Quaternary, Middle Permian and Proterozoic (Fig. 3A). Granite gneiss and amphibolites with few patches of Quaternary newer alluvium are found over the northern segments. Granitic gneiss is hard as well as compact in character with slight primary porosity and permeability but are turn into absorbent and permeable resulted from secondary porosity by fracturing and weathering of rock strata (CGWB 2009). Dug wells and bore wells or dug-cum-bore wells are feasible in this with the yield 
prospect $0.18-96 \mathrm{cum} / \mathrm{hr}$ (CGWB 2009). Quaternary laterite with deposits of Illambazar surface of Middle Proterozoic periods mainly concentrated in the eastern and south-eastern part of Dubrajpur block. Laterite provides a prolific subsurface water reservoir due to its high-quality porosity and permeability (CGWB 2014; Das and Mukhopadhyay 2018). Low- to heavy-duty tube wells are feasible where the yield prospect is $7.2-250 \mathrm{cum} / \mathrm{hr}$. So, laterite has been given complex penchant than the granitic gneiss. Rest of the parts are under the newer alluvium of deposited by River Ajay and its tributaries and numerous first- and second-order streams.

\section{Lineament study}

Lineaments manipulate the infiltration rate and facilitate to recharge of subsurface water storage which can be effortlessly recognized from satellite images (Rao et al. 2001; Jhariya et al. 2016). Here, lineaments are extracted from satellite imagery and District resources map provided by GSI. Most of the lineaments area mainly concentrated in the northern part of the study area which predominated by hard rock terrain formed with granite, gneiss and amphibolites rock of Proterozoic periods. Southern part of study area is completely devoid of any intersection of lineaments (Fig. 3A). Lineaments intersection can also take part in important role in groundwater accumulation, whereas areas with minimum occurrence of lineaments which have poor groundwater potential are specified with lower weightage.

\section{Hydro-geomorphology}

In present study, hydro-geomorphological set-up has been identified from high-resolution satellite image and geohydrological features of the study region. Seven specific hydro-geomorphic units are identified in the study region which includes alluvial plain older, alluvial plain younger predominantly in the south-eastern part adjoining to Ajay River. Lateritic plain with dissected lateritic upland along with few patches of buried pediment medium (BPM) and buried pediment shallow (BPS) concentrated the major portion (i.e. $57.86 \%$ to total area) of the study region covering the northern part. Weathered pediments and valley fills few patches in the extreme north of the study area (Fig. 3B). The alluvial plain both the older and younger and valley fill (mainly drainage and streams lines) in the southern part (i.e. covers $40 \%$ total area) are précised utmost weightage since these are very good potential sites for subsurface water recharge as precipitated water can effortlessly penetrate in this points annually (Das 2016). Lateritic plain along with dissected lateritic upland in the northern part assigned less weightage as these points ones are primarily runoff area endowed with less permeability. Buried pediments medium (BPM) has superior recharge capacity than the Buried pediments shallow (BPS) because the former surface mainly consists of unconsolidated weathered material overburden by thick alluvium or gravels which acts as a lofty groundwater recharge source in the study area (Fig. 3B).

\section{Slope}

Slope is incorporated in present study as an imperative topographic factor as well as indicators surface configuration to measure potentiality of groundwater (Al Saud 2010). This element of land determines the rate of surface runoff and percolation of water to subsurface which ultimately affects recharge processes (Adiat et al. 2012; Bhunia et al. 2012; Kumar et al. 2014). Beside this, as the rate of infiltration is inversely associated with the slope factor, the slope of higher percentage value has been given low priority and vice versa (Rahmati et al. 2015). In present study, slope has been organized from SRTM DEM elevation data with $30 \mathrm{~m}$ spatial resolution in GIS environment (Fig. 2C). Maximum slope recorded in this area is $4.059^{\circ}$, whereas average slope is $1.22^{\circ}$. Central parts of this block have comparatively more slope than the northern and southern part.

\section{Soil texture}

Soil plays an essential role encouraging or discouraging the recharge of subsurface water resources and keep of surface water in any region (Biswas and Mukherjee 1994). Mainly the textural properties of the soil are the determining features to the control of percolation rate and recharge of subsurface resources (Das and Mukhopadhyay 2018). The soil texture of the study has been prepared following the guidelines of NBSS and LUP. Dubrajpur block has been dissected into five major soil textural groups, viz. Loamy, Loamy skeletal, Shallow Loamy, Fine loam and very fine loam (Fig. 3D). There is a sharp divide in between northern and southern part of the study are on the basis of textural class of soil, i.e. northern part is endowed with loamy to loamy skeletal soil whereas southern part is composed with fine and very fine loamy soil. Undulating plain along with land with gentle slope in the northern part is mainly composed with Loamy skeletal, shallow loamy soil (47\% to total area) which is less potential for percolation and groundwater recharge (Fig. 3D). Southern part which is mainly composed with river born alluvium of different streams is endowed with fine to very fine loamy soil those have better percolation and groundwater recharge capacity than the northern part.

\section{Land use and land cover}

Different types of land use-land cover are a significant sign of the level of groundwater prerequisite and consumption, 
as well as these categories provide information about the recharge of subsurface water (Singh et al. 2011; Das and Pal 2019). A number of land use landcover types have been identified in the study area namely water bodies, vegetation, built-up area, agricultural and others which mainly covers the barren land, as well as fallow land (Fig. 3E). The LULC classes are assessed by supervised method in GIS platform by incorporating satellite images of IRS P6-LISS III data, as well as landform features from SOI Topographical map and concentrated field authentication. A total 75 points, i.e. 15 points of each class have been incorporated to confirm the accuracy level which shows that the overall accuracy and Kappa coefficient of present classification are 89.67. Major land use has been covered by agricultural land, i.e. 136.88 sq $\mathrm{km}$. (38.3\%) followed by built up area $(96.48 \mathrm{sq} \mathrm{km}$., i.e. $27 \%$ to total area) and vegetation which covers overall 80.77 sq $\mathrm{km}$, i.e. $22.6 \%$ to total area. To identify overall surface water bodies, normalized difference water index (NDWI) has been prepared (Fig. 3F) which explains the facts that major share of water bodies are covered mainly by Bakreshwar Dam in the central part of Dubrajpur block and numerous streams and tributaries of river Ajay and Mayurakshi, whereas vegetation patches are ample around the dam region. Vegetation has a key role to play in the subsurface water recharge practice because it augmented the infiltration rate by clutching the precipitated water. Water bodies along with fallow lands and vegetative covers are more constructive than agricultural lands and built-up area for groundwater recharge. Weightage has been assigned in order to water bodies, agricultural land, vegetation and built-up area as per their ability to enhance the recharge procedure.

\section{Depth to groundwater level study}

Two season-based (pre-monsoon and post-monsoon) groundwater level reflects the actual groundwater condition of the area, whereas groundwater recharge can be estimated by the difference between the water level in different season, i.e. water level fluctuation. Results have been prepared from the volume of water table differences between the pre-monsoon and post-monsoon and in observable wells which have been collected from the database provided by the Central Ground Water Board (CGWB: http://cgwb.gov. in/ GW-data-access.html). In pre-monsoon season, eastern most part of the study area has water level more accessible, whereas southern alluvial plain has high level of water level. In post-monsoon season, the northern part composed with hard rock has more accessible water level than the southern alluvial plain (Fig. $3 \mathrm{G}$ andH). Groundwater fluctuation is maximum in both the eastern and western corner of the study area which put more hindrance against good groundwater potentiality (Fig. 3I). So high level of fluctuation has been assigned low potential weight and vice versa.

\section{Weight generation of layers and application of AHP}

Each thematic layer of different contributing inputs has been classified into different segments based on their range value, and ranking process has been included to allot normalized weight for every mark of an input layer. Analytical Hierarchy Process (AHP) model initially introduced by Saaty (1980) has been functional to accommodate normalized weight for each contributing inputs. As this hierarchy model is the extensively acknowledged multi-criteria decision-making practice which is used predominantly in the domain of any resource management as it enables to fester as well as to make pairwise comparison, that trim down the discrepancy and provides priority vector (Rahmati et al. 2015; Das and Mukhopadhyay 2018; Saaty 1999; Razandi et al. 2015). After thorough application of AHP model, the pairwise comparison matrix of all contributing thematic layer (e.g. geology, lineament, LULC, etc.) has been derived (Table 1) and the normalized weight for each thematic layer has been resolute by scheming priority vector. Groundwater potential index (GWPI) is a dimensionless quantitative process which enables to demarcate groundwater potential zone in the study area (Rahmati et al. 2015; Razandi et al. 2015). Based on the mentioned methodology, as well as deal of pixels in GIS platform, the ultimate outcome of groundwater potential zones has been branded into three classes, e.g. excellent potentiality with expected yield range between 100 and $200 \mathrm{~L}$ per minute, good to moderate potentiality with expected yield range between 75 and $100 \mathrm{~L}$ per minute and moderate to poor with yield range between 75 and $100 \mathrm{~L}$ per minute. Each of potential zones covers different percentage of area, e.g. excellent potential zone has area coverage of $146.6 \mathrm{sq} \mathrm{km}$., i.e. $41 \%$ to total area of the study region followed by $193.45 \mathrm{sq} \mathrm{km}$. ( $54.5 \%$ to total area) by good to moderate potential zone, whereas moderate to poor potential area covers very less area of $17.35 \mathrm{sq} \mathrm{km}$. area which are mainly concentrated in the northern most part endowed with hilly tract and rugged dissected plateau.

\section{Discussions}

In present investigation, pairwise comparison matrix of eight contributing layers has been derived by applying AHP model (Tables 1 and 2), whereas the normalized weight for each inputs has been resolute by calculating priority vector (Table 2). It is a well-established fact from Table (2) that hydro-geomorphology which occupies $30.8 \%$ weightage as it is the prime input parameter to recharge subsurface resources followed by Slope (19.5\%) and Geological setup (19.3\%) jointly places second most significant inputs which influence groundwater potentiality in this region. Following the same way, Land use Land cover (9.6\%), water level (9.8\%), Lineament density (5.6\%) and soil texture (5.3\%), respectively, 
Table 1 Pairwise comparison matrix of eight variables

\begin{tabular}{|c|c|c|c|c|c|c|c|c|}
\hline Class & $\begin{array}{l}\text { Hydro-geomor- } \\
\text { phology }\end{array}$ & Slope & Geology & LULC & Water level & Lineament & Soil texture & NDWI \\
\hline Hydro-geomorphology & 1 & 6 & 5 & 2 & 5 & 3 & 4 & 3 \\
\hline Slope & 0.166 & 1 & 6 & 5 & 0.5 & 4 & 4 & 2 \\
\hline Geology & 0.2 & 0.167 & 1 & 7 & 4 & 6 & 4 & 3 \\
\hline LULC & 0.5 & 0.2 & 0.143 & 1 & 3 & 2 & 2 & 0.333 \\
\hline Water level & 0.2 & 2 & 0.25 & 0.333 & 1 & 0.5 & 6 & 0.25 \\
\hline Lineament & 0.333 & 0.25 & 0.1666 & 0.5 & 2 & 1 & 0.333 & 3 \\
\hline Soil texture & 0.25 & 0.25 & 0.25 & 0.5 & 0.167 & 3 & 1 & 2 \\
\hline NDWI & 0.333 & 0.5 & 0.333 & 3 & 2 & 0.333 & 0.25 & 1 \\
\hline SUM & 2.982 & 10.367 & 13.1426 & 19.333 & 17.667 & 19.833 & 21.583 & 14.583 \\
\hline
\end{tabular}

AHP Scale: 1 Equal Importance, 3 moderate, 5 Strong Importance, 7 Very Strong importance; 2, 4, 6, 8 intermediate Values; 1/3, 1/5. 1/7 Values of inverse Comparison

Table 2 Normalized Pairwise Comparison Matrix of Eight Variables

\begin{tabular}{lllllllllll}
\hline Class & $\begin{array}{l}\text { Hydro-geo- } \\
\text { morphology }\end{array}$ & Slope & Geology & LULC & Water level & Lineament & Soil texture & NDWI & Criteria Weight & $\%$ \\
\hline Hydro-Geomorphology & 0.335 & 0.579 & 0.380 & 0.103 & 0.283 & 0.151 & 0.185 & 0.206 & 0.278 & 27 \\
Slope & 0.056 & 0.096 & 0.457 & 0.259 & 0.028 & 0.202 & 0.185 & 0.137 & 0.177 & 18 \\
Geology & 0.067 & 0.016 & 0.076 & 0.362 & 0.226 & 0.303 & 0.185 & 0.206 & 0.180 & 18 \\
LULC & 0.168 & 0.019 & 0.011 & 0.052 & 0.170 & 0.101 & 0.093 & 0.023 & 0.079 \\
Water level & 0.067 & 0.193 & 0.019 & 0.017 & 0.057 & 0.025 & 0.278 & 0.017 & 0.084 & 8 \\
Lineament & 0.112 & 0.024 & 0.013 & 0.026 & 0.113 & 0.050 & 0.015 & 0.206 & 0.070 \\
Soil texture & 0.084 & 0.024 & 0.019 & 0.026 & 0.009 & 0.151 & 0.046 & 0.137 & 0.062 & 7 \\
NDWI & 0.112 & 0.048 & 0.025 & 0.155 & 0.113 & 0.017 & 0.012 & 0.069 & 0.069 & 7 \\
\hline
\end{tabular}

Random Index for eight samples is 1.41 which is greater than result 0.371

$\lambda$ max value 11.248; Consistency Index (CI) 0.464; Consistency Ratio (CR) 0.407

engage their weightage and position concerning the control of groundwater potential in Dubrajpur Block. Analysis of pairwise comparison matrix also discovered that all the contributing factors included in present study are the prominent factors for identification of the groundwater potentiality in the study area (Table 1). The degree of consistency achieved in the weighting is measured by a consistency ratio (CR) signifying the probability that matrix weighting was randomly generated. Revising the matrix requires finding inconsistent decisions regarding to the importance of criteria. To verify the reliability of the conclusion concerns the influence of prospecting factors or the selected contributing layers, Saaty's ratio index (1980) for different values has been inferred. Revising these decisions by comparing again the pairs of criteria is considered inconsistent. But in present study Consistency Ratio (CR) 0.371 which is less than the Random Index values for seven samples is 1.32 which makes decision that the result the selection of the indicators with their association are very much relevance to identify the potential region of groundwater resources of the study area (Table 2).

The spatial outlook of potentiality of occurrence of groundwater reveals that the potentiality is strongly controlled by the physical parameters like hydro-geomorphology, geological setup, and slope. Groundwater potential zone (Fig. 4) explains that the south and south-eastern part of the Dubrajpur Block contain excellent groundwater potential because these regions are characterized by lesser degree of slope, the presence of alluvial deposit, and fine to very fine loam soil texture which cumulatively allow infiltrating groundwater in this segment. As a result, this part of the study area contains high expected yield rate of wells ranging between 100 and 200 LPM. On contrary, northern, as well as western, part of Dubrajpur Block represents good to moderate groundwater potentiality due to presence of granite and gneiss hard rock with amphibolites which have very limited primary porosity as well as having little influence on groundwater recharge. Except of this situation in the regions with good to moderate potentiality, 
Fig. 4 Groundwater Potential Zone of the Study Area

Groundwater Potential Zone

Dubrajpur Block, Birbhum District, West Bengal

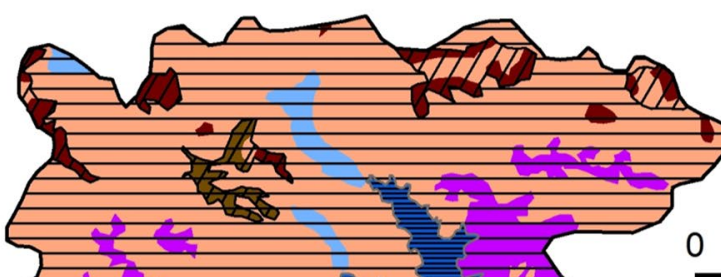

0

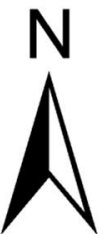

$\mathrm{N}$

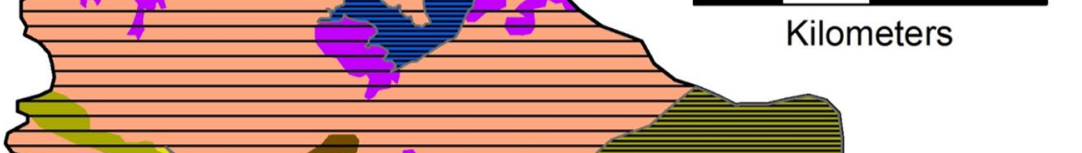

Geomorphic Units

Weathered pediplain

Buried pediment shallow

Buried poediment medium

Dissected lateritic upland

Lateritic Plain

Alluvial plain older

Alluvial plain younger
Groundwater potentials

Moderate to poor

Good to moderate

Good to moderate

Moderate to poor

Good to moderate

Excellent

Excellent some groundwater potentiality takes place for the occurrence of numerous lineaments and joint which allow the precipitated water to penetrate in the subsurface strata. Moderate to poor potentiality has been found in very limited region in the extreme northern part of the study area which endowed with the comparatively high degree of slope and loamy skeletal soil formed mainly by weathered materials (Fig. 4). (Table 3).

Nowadays, marking out of groundwater potential zone in context of lofty requirement of groundwater is principally very obligatory as prospective of groundwater gives an opening for thinkers and future development of that particular subsurface resource by the planners. Pushing by such reason identification of high to moderate and low groundwater potentiality in this sub-district level gives a design to the regional planner about how these obtainable water resources can be used judiciously and how it can facilitate the positivity to the future generation users.
Though the result of current study is quiet reliable, some limitations are still there. The AHP model is basically based on the opinion given by practioners, so there may be error in their decision in terms of the potential zone. Other parameters like the quantity of drafting of water for irrigation and miscellaneous domestic uses have not been taken into consideration but these items have considerable impact on groundwater potential.

\section{Validation of the model}

Validation of the classified groundwater potential zone is one of the major steps towards the successful implementation of management plan. In fact enhancing accuracy in the classification helps the planner to adopt proper strategy for management. So, as a corollary of the above discussion, an attempt has been made to assess the level of accuracy of the classified potential zone using 30 real 
Table 3 Assigned and normalized weights of different features of eight thematic layers

\begin{tabular}{|c|c|c|c|c|}
\hline Class & Sub Class & Groundwater potential & $\begin{array}{l}\text { Assigned } \\
\text { rank }\end{array}$ & Weightage (\%) \\
\hline \multirow[t]{4}{*}{ Hydro-geomorphology } & Alluvial Plain & Very good & 5 & 27 \\
\hline & Lateritic Plain & Good & 3 & \\
\hline & Buried Pediment & Moderate & 2 & \\
\hline & Pediplain(Weathered) & Poor & 1 & \\
\hline \multirow[t]{4}{*}{ Slope } & Very $\operatorname{low}\left(<1^{0}\right)$ & Very good & 5 & 18 \\
\hline & Moderately Low $\left(1^{0}-2^{0}\right)$ & Good & 3 & \\
\hline & $\operatorname{Low}\left(2^{0}-3^{0}\right)$ & Moderate & 2 & \\
\hline & $\operatorname{Medium}\left(>4^{0}\right)$ & Poor & 1 & \\
\hline \multirow[t]{3}{*}{ Geology } & Alluvium & Very good & 5 & 18 \\
\hline & Shale & Moderate & 3 & \\
\hline & Granitic gneiss & Poor & 1 & \\
\hline \multirow[t]{5}{*}{ LULC } & Water bodies & Very good & 5 & 8 \\
\hline & Forest land & Good & 4 & \\
\hline & Agricultural Land & Moderate & 3 & \\
\hline & Others & Moderate & 3 & \\
\hline & Built up area & Poor & 1 & \\
\hline \multirow[t]{3}{*}{ Groundwater fluctuation } & Low $(<2 \mathrm{~m})$ & Very good & 5 & 8 \\
\hline & Moderate $(2-4 \mathrm{~m})$ & Good & 3 & \\
\hline & $\operatorname{High}(>4 \mathrm{~m})$ & Poor & 1 & \\
\hline \multirow[t]{3}{*}{ Lineament density } & $>0.2 \mathrm{~km} / \mathrm{km} 2$ & Good & 3 & 7 \\
\hline & $0.1-0.2 \mathrm{~km} / \mathrm{km} 2$ & Moderate & 2 & \\
\hline & $<0.1 \mathrm{~km} / \mathrm{km} 2$ & poor & 1 & \\
\hline \multirow[t]{3}{*}{ Soil texture } & Coarse loam & Very good & 5 & 7 \\
\hline & Fine loam & Good & 3 & \\
\hline & Skeletal & Moderate & 2 & \\
\hline \multirow[t]{3}{*}{ NDWI } & $-0.15-0.0$ & Poor & 2 & 7 \\
\hline & $0.0-+0.15$ & Moderate & 3 & \\
\hline & $+0.15-+0.3$ & Very good & 5 & \\
\hline
\end{tabular}

borehole data from the study area. Location of the bore hole is presented in Table 4. Having a proper knowledge over those data the yield range has been classified into five classes, and each class has been assigned with a qualitative remark that will be helpful to compare the data with the classified potential zone. It has been found that out of 30 points 8 have not conformed to the classified potential zone. Rest of the 22 points are more or less matches with the predicted zone. Hence, the final output yields almost $73 \%$ accuracy. Considering the importance of the study, a more rigorous method has been attempted in this study to cross-check the accuracy of the model which is sensitivity and specificity analysis between the collected data and final potential zone. This method has widely been applied to assess the reliability of any sample data. Under sensitivity, true positive and false negative rate has been calculated, and under specificity, true negative rate and false positive rate has been computed. The result has been depicted as receiver operating characteristics curve on Fig. 5. The chart shows an area under curve (AUC) value of 0.698 that means almost $69.8 \%$ of the area falls under the curve. So, the model can be accepted as it predicts almost $70 \%$ of the data accurately.

\section{Management proposal}

To manage the subsurface water resources primarily, we should reduce the dependency on these particular resources for our daily need, as well as it is also viable to searching of alternative sources of water. Augmentation of groundwater recharge is also very much pertinent way to enhance these resources. For this reason, some recharge well (10 No.) structure and recharge pit (11 No.) have been identified all over the study area which can be used for groundwater recharge 
Table 4 Depth of groundwater collected from borehole

\begin{tabular}{|c|c|c|c|c|c|c|c|c|}
\hline S1 No & Latitude (North) & Longitude (East) & $\begin{array}{l}\text { Actual } \\
\text { yield* (m) } \\
(\text { Apr 16) }\end{array}$ & $\begin{array}{l}\text { Actual yield* } \\
(\mathrm{m})(\text { Nov } 16)\end{array}$ & Fluctuation (m) & Remark & $\begin{array}{l}\text { Expected yield } \\
\text { from prediction }\end{array}$ & $\begin{array}{l}\text { Agreement/ } \\
\text { Disagree- } \\
\text { ment }\end{array}$ \\
\hline 1 & 23.6242 & 87.5389 & 24.7 & 18.66 & 6.04 & Excellent & Excellent & Yes \\
\hline 2 & 23.7039 & 87.4467 & 18.35 & 16.2 & 2.15 & Excellent & Excellent & Yes \\
\hline 3 & 23.7525 & 87.4086 & 6.95 & 3.98 & 2.97 & Moderate to good & Moderate to good & Yes \\
\hline 4 & 23.7525 & 87.4089 & 9.3 & 7.4 & 1.9 & Moderate to good & Moderate to good & Yes \\
\hline 5 & 23.7594 & 87.5358 & 20.21 & 16.04 & 4.17 & Excellent & Excellent & Yes \\
\hline 6 & 23.7631 & 87.5219 & 8.3 & 7.9 & 0.4 & Moderate to good & Excellent & No \\
\hline 7 & 23.7836 & 87.3872 & 7.18 & 5.45 & 1.73 & Moderate to good & Poor to moderate & No \\
\hline 8 & 23.7856 & 87.3569 & 4.35 & 2.85 & 1.5 & Poor to mod & Moderate to good & No \\
\hline 9 & 23.7858 & 87.3419 & 4.55 & 2.4 & 2.15 & Poor to mod & Moderate to good & No \\
\hline 10 & 23.7894 & 87.4950 & 2.6 & 2.15 & 0.45 & Poor to mod & Excellent & No \\
\hline 11 & 23.7903 & 87.2686 & 6.7 & 4.4 & 2.3 & Moderate to good & Moderate to good & Yes \\
\hline 12 & 23.7936 & 87.4933 & 4.05 & 2.1 & 1.95 & Poor to mod & Poor to mod & Yes \\
\hline 13 & 23.8000 & 87.5283 & 5.9 & 4 & 1.9 & Moderate to good & Moderate to good & Yes \\
\hline 14 & 23.8336 & 87.4917 & 3.4 & 2.9 & 0.5 & Poor to mod & Poor to mod & Yes \\
\hline 15 & 23.8503 & 87.2747 & 4.6 & 2.9 & 1.7 & Poor to mod & Poor to mod & Yes \\
\hline 16 & 23.8544 & 87.5011 & 2.05 & 1.87 & 0.18 & Poor to mod & Moderate to good & No \\
\hline 17 & 23.8697 & 87.2842 & 5.5 & 3.4 & 2.1 & Moderate to good & Poor to moderate & No \\
\hline 18 & 23.8750 & 87.5189 & 2.54 & 0.7 & 1.84 & Poor to mod & POOR to mod & Yes \\
\hline 19 & 23.8814 & 87.3750 & 2.84 & 2.6 & 0.24 & Poor to mod & Poor to mod & Yes \\
\hline 20 & 23.8836 & 87.5483 & 14.1 & 5.4 & 8.7 & Excellent & Excellent & Yes \\
\hline 21 & 23.8842 & 87.5317 & 7.85 & 5.4 & 2.45 & Moderate to good & Moderate to good & Yes \\
\hline 22 & 23.8853 & 87.5325 & 9.3 & 6.4 & 2.9 & Moderate to good & Moderate to good & Yes \\
\hline 23 & 23.9128 & 87.4936 & 6.7 & 4.6 & 2.1 & moderate to good & Moderate to good & Yes \\
\hline 24 & 23.9175 & 87.3939 & 6.95 & 4.7 & 2.25 & Moderate to good & Moderate to good & Yes \\
\hline 25 & 23.9183 & 87.5200 & 5.95 & 4.55 & 1.4 & Moderate to good & Moderate to good & Yes \\
\hline 26 & 23.9206 & 87.4400 & 4.45 & 3 & 1.45 & Poor to mod & Poor to mod & Yes \\
\hline 27 & 23.9211 & 87.5189 & 3.5 & 2.3 & 1.2 & Poor to mod & Poor to mod & Yes \\
\hline 28 & 23.9247 & 87.4364 & 3.01 & 2.65 & 0.36 & Poor to mod & Moderate to good & No \\
\hline 29 & 23.9425 & 87.3089 & 6.32 & 3.8 & 2.52 & Moderate to good & Moderate to good & Yes \\
\hline 30 & 23.9439 & 87.3231 & 8.28 & 6.3 & 1.98 & Moderate to good & Moderate to good & Yes \\
\hline
\end{tabular}

*Source: Central Ground Water Board (CGWB)

enhancement (Fig. 6). Recharge well is more or less uniformly distributed over the region, whereas maximum number of recharge pit have been identified over the northern part where the groundwater potentiality level belongs to good to moderate with expected yield rate 75 to 100 LPM. More attention should be paid for the northern part of the study area as this region is mainly composed of hard rock of granite and gneiss with amphibolites, as well as endowed with laterite upland. More than 35 numbers of ponds have been excavated nowadays to store the rainwater for different uses which can also have a tendency to percolate as well as recharge the groundwater storage (Fig. 6). Distillation of eastern canal as well as binding of three check dams in the northern part across the stream connecting Bakreshwar dam may be fruitful way to reduce the use of groundwater in this region.

\section{Conclusion}

Nowadays, water crisis mainly in terms of decline in groundwater level is a massive problem in any monsoondominated region where precipitated rainwater and groundwater are sole resources for farm-based activities and other uses. In present work, multicriteria decision analysis using AHP model along with application of remote sensing and GIS techniques have been incorporated to delineate the groundwater potential zone in the western part of the Birbhum district of West Bengal. From the analysis, it is clear that $42 \%$ area of the sub-district have excellent potentiality with expected yield range between 100 and $200 \mathrm{~L}$ per minute. From the multi-criteria decision, it is also clear that physiographical input like hydro-geomorphology, slope and 


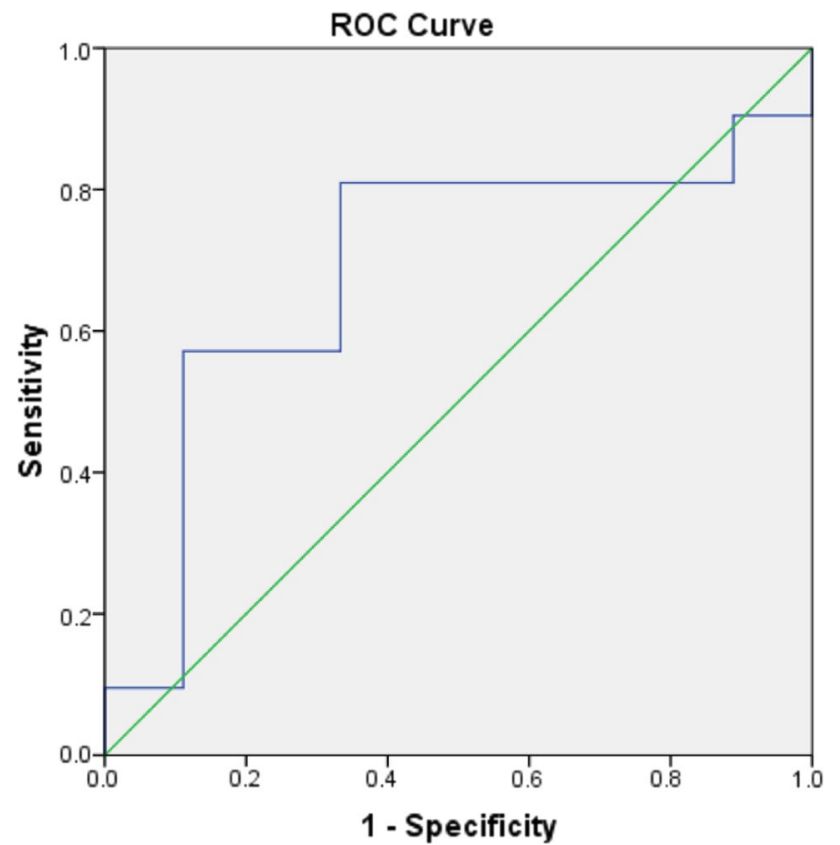

Fig. 5 Receiver operating characteristics curve (ROC) for validation of groundwater potential zone. $\mathrm{AUC}=0.698$ geological background has better control over this spatial outlook of groundwater potentiality. Though the good to moderate potential region spread over $54.4 \%$ region, this potentiality may be enhanced by some techniques and by minimizing the rigidity of terrain characteristics. This enhancement may engage with establishment of recharge pit and recharge well in some joint and fractured zone as this region is mainly composed with hard granite and gneiss with amphibolites. From the multi-criteria decision, it is also clear that physiographical input like hydro-geomorphology, slope and geological background has better control over this spatial outlook of groundwater potentiality. To manage these resources first and foremost, we should move towards reduction in the dependency on particular resources, as well as it is also viable to searching of alternative sources of water. Augmentation of groundwater recharge is also very much pertinent way to enhance these resources. Eastern canal is a important alternative in this regard along with binding of three check dams in the northern part across the stream connecting Bakreshwar dam may be productive hand to trim down the utilization of subsurface water resources in Dubrajpur Block and adjoining regions. This kind of work is quiet matter-of-fact in the time of resource depletion because this
Fig. 6 Groundwater Management proposal in the study area

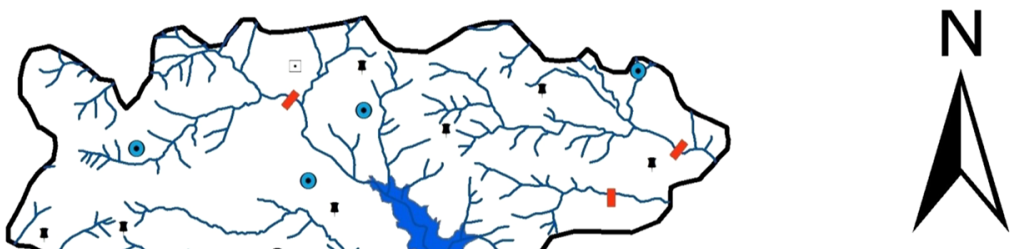

○ Recharge_well

- Recharge_pit

- Excavation of pond

Desiltation of canal

Check dam

Bakeswar Reservoir 
final output of groundwater potentiality will be supportive to the organizations who are engaged in surface and subsurface water resource management. Besides this, it is also accommodating to the local inhabitants as they can identify the effective drilling area to extract more groundwater resource.

Funding No fund has been taken to accomplish the study.

\section{Declarations}

Conflict of interest The authors declare that they have no conflicts of interest.

Human and animal rights The question of harm or participation of the animals and people is not applicable in the present context as the study is not associated about them.

Open Access This article is licensed under a Creative Commons Attribution 4.0 International License, which permits use, sharing, adaptation, distribution and reproduction in any medium or format, as long as you give appropriate credit to the original author(s) and the source, provide a link to the Creative Commons licence, and indicate if changes were made. The images or other third party material in this article are included in the article's Creative Commons licence, unless indicated otherwise in a credit line to the material. If material is not included in the article's Creative Commons licence and your intended use is not permitted by statutory regulation or exceeds the permitted use, you will need to obtain permission directly from the copyright holder. To view a copy of this licence, visit http://creativecommons.org/licenses/by/4.0/.

\section{References}

Adiat KAN, Nawawi MNM, Abdullah K (2012) Assessing the accuracy of GIS based elementary Multi-criteria decision analysis as a spatial prediction tool-a case of predicting potential zones of sustainable groundwater resources. J Hydrol 440:79-89. https:// doi.org/10.1016/j.jhydrol.2012.03.028

Agarwal E, Agarwal R, Garg RD, Garg PK (2013) Delineation of groundwater potential zone: an AHP/ANP approach. J Earth Syst Sci 122(3):887-898

Al Saud M (2010) Mapping potential areas for groundwater storage in Wadi Aurnah basin, western Arabian Peninsula, using remote sensing and geographic information system techniques. Hydrogeol J 18:1481-1495. https://doi.org/10.1007/s10040-010-0598-9

Aladejana OO, Anifowose AYB, Fagbohun BJ (2016) Testing the ability of an empirical hydrological model to verify a knowledgebased groundwater potential zone mapping methodology. Modeling Earth Syst Environ 2(4):174

Ayazi MH, Pirasteh S, Arvin AKP, Pradhan B, Nikouravan B, Mansor S (2010) Disasters and risk reduction in groundwater: Zagros Mountain Southwest Iran using geo-informatics techniques. Disaster Adv 3(1):1-8

Bagchi K, Mukherjee KN (1983) Diagnostic survey of Rarh Bengal. Calcutta University, The project from Geography Department, Calcutta

Bhunia GS, Samanta S, Pal B, Memorial R, Agamkuan S (2012) Deciphering prospective groundwater zones of Morobe province, Papua New Guinea. Int J Eng Appl 2(3):752-766
Biswas A, Jana A, Sharma SP (2012) Delineation of Groundwater potential zones using satellite remote sensing and geographic information techniques: a case study from Gunjam district, Orissa. India Res J Recent Sci 1(9):59-66

Black M, Talbot R (2005) Water, a matter of life and health: water supply and sanitation in village India. Oxford University Press, Noida

Central Ground Water Board (2020): Ground Water Year Book of West Bengal \& Andaman \& Nicobar Islands (2019-2020), Eastern Region Kolkata. http://cgwb.gov.in/Regions/ER/Reports/ GWYB\%202019-2020\%20WB\%20\&\%20AN.pdf

CGWB. (2009). Report of the groundwater resource estimation committee (pp. 8-12). New Delhi: Ministry of Water Resources, Government of India

CGWB. (2014).Groundwater Year Book of West Bengal and Andaman and Nicobar Island 2014-15. Ministry of Water Resources, Government of India. http://www.cgwb.gov.in. Accessed January 29, 2021.

Chenini I, Mammou AB, May ME (2010) Groundwater recharge zone mapping using GIS based multi-criteria analysis: a case study in Central Tunisia (Maknassy Basin). Water Resour Manage 24(5):921-939

Chowdhury A, Jha MK, Chowdhury VM (2010) Delineation of groundwater recharge zones and identification of artificial recharge sites in West Medinipur district, West Bengal, using RS, GIS and MCDM techniques. Environ Earth Sci 59:1209-1222. https:// doi.org/10.1007/s12665-009-0110-9

Chowdhury A, Jha MK, Chowdhury VM, Mal BC (2009) Integrated remote sensing and GISbased approach for assessing groundwater potential in West Medinipur district, West Bengal, India. Int J Remote Sens 30:231-250

Dasho OA, Ariyibi EA, Akinluyi FO, Awoyemi MO, Adebayo AS (2017) Application of satellite remote sensing to groundwater potential modeling in Ejigbo area. Southwestern Nigeria Model Earth Syst Environ 3(2):615-633

Das B, and Pal SC (2019) Assessment of groundwater recharge and its potential zone identification in groundwater-stressed Goghat-I block of Hugli District, West Bengal, India. Environment, Development and Sustainability, 1-19

Das N, Mukhopadhyay S (2018) Application of multi-criteria decision making technique for the assessment of groundwater potential zones: a study on Birbhum district, West Bengal, India. Environ Dev Sustain 22(2):931-955

Das S (2017) Delineation of groundwater potential zone in hard rock terrain in Gangajalghati block, Bankura district, India using remote sensing and GIS techniques. Model Earth Syst Environ 3(4):1589-1599

Deepa S, Venkateswaran S, Ayyandurai R, Kannan R, Prabhu MV (2016) Groundwater recharge potential zones mapping in upper Manimuktha Sub basin Vellar river Tamil Nadu India using GIS and remote sensing techniques. Modeling Earth Syst Environ 2(3): 137

District Census Handbook Birbhum, Census of India 2011, Series 20, Part XII A" (PDF). Page 15: Physiography. Directorate of Census Operations, West Bengal.

Ganapuram S, Kumar GTV, Krishna IVM, Kahya EM, Demirel C (2009) Mapping of groundwater potential zones in the Musi basin using remote sensing data and GIS. Adv Eng Softw 40:506-518

Haridas VR, Aravindan S, Girish G (1998) Remote sensing and its applications for groundwater favorable area identification. Quarterly J Geol Assoc Res Centre 6:18-22

Holden J (2014) Water resources: an integrated approach. Routledge, New York

Hutti B, Nijagunappa R (2011) Identification of groundwater potential zone using Geoinformatics in Ghataprabha basin, North Karnataka, India. Int J Geomat Geosci 2(1):91-109 
http://cgwb.gov.in/District_Profile/WestBengal/Birbhum accessed on 06.03.2020.

Jha MK, Chowdary VM, Chowdhury A (2010) Groundwater assessment in Salboni Block, West Bengal (India)using remote sensing, geographical information system and multi-criteria decision analysis techniques. Hydrogeol J 18(7):1713-1728. https://doi. org/10.1007/s10040-010-0631-z

Jhariya DC, Kumar T, Gobinath M, Diwan P, Kishore N (2016) Assessment of groundwater potential zone using remote sensing, GIS and multi-criteria decision analysis techniques. J Geol Soc India 88:481-492

Kaliraj S, Chandrasekar N, Magesh NS (2014) Identification of potential groundwater recharge zones in Vaigai upper basin, Tamil Nadu, using GIS-based analytical hierarchical process (AHP) technique. Arab J Geosci 7(4):1385-1401. https://doi.org/10. 1007/s12517-013-0849-x

Kumar T, Gautam AK, Kumar T (2014) Appraising the accuracy of GIS based multi criteria decision making technique for delineation of groundwater potential zones. Water Res Manage 28:44494466. https://doi.org/10.1007/s11269-014-0663-6

Magesh NS, Chandrasekar N, Soundranayagam JP (2012) Delineation of groundwater potential zones in Theni district, Tamil Nadu, using remote sensing. GIS and MIF Tech Geosci Front 3(2):189-196

McNeill JD (1991). Advances in electromagnetic methods for groundwater studies. Geoexploration, 27:65-80

Meijerink AMJ (1996) Remote sensing applications to hydrology: groundwater. Hydrol Sci J 41(4):549-56

Machiwal D, Jha MK, Mal BC (2011) Assessment of groundwater potential in a semi-arid region of India using remote sensing, GIS and MCDM techniques. Water Resour Manage 25:1359-1386

Madrucci V, Taioli F, Cesar de Araujo C (2008) Groundwater favorability map using GIS multicriteria data analysis on Crystalline terrain, Sao Paulo State, Brazil. J Hydrol 357:153-173. https:// doi.org/10.1016/j.jhydrol.2008.03.026

Mukherjee P, Singh CK, Mukherjee S (2012) Delineation of groundwater potential zone in aridregion of India-A remote sensing and GIS approach. Water Resour Manage 26:2643-2672. https://doi. org/10.1007/s11269-012-0038-9

Mondal D, Gupta S, Reddy DV, Nagabhushanam P (2014) Geochemical controls on fluoride concentrations in groundwater from alluvial aquifers of the Birbhum district, West Bengal, India. J Geochem Explor 145:190-206. https://doi.org/10.1016/j.gexplo. 2014.06.005

Nag SK, Ray S (2015) Deciphering groundwater potential zones using geospatial technology: a study in Bankura Block I and Block II,
Bankura District, West Bengal. Arab J Sci Eng 40:205-214. https://doi.org/10.1007/s13369-014-1511-y

Rahmati O, Nazari Samani A, Mahdavi M, Pourghasemi HR, Zeinivand H (2015) Groundwater potential mapping at Kurdistan region of Iran using analytic hierarchy process and GIS. Arab J Geosci 8(9):7059-7071. https://doi.org/10.1007/s12517-014-1668-4

Rao NS, Chakradhar GKJ, Srinivas V (2001) Identification of groundwater potential zones using remote sensing techniques in an around Gunur town, Andhra Pradesh, India. J Ind Soc Remote Sens 29:69-78. https://doi.org/10.1007/BF02989916

Razandi Y, Pourghasemi HR, Neisani NS (2015) Application of analytical hierarchy process, frequency ratio and certainty factor models for groundwater potential mapping using GIS. Earth Sci Inf 8(4):883-886. https://doi.org/10.1007/s12145-015-0220-8

Sar N, Khan A, Chatterjee S, Das A (2015) Hydrologic delineation of ground water potential zones using geospatial technique for Keleghai river basin. India Modeling Earth Syst Environ 1(3):25

Sander P, Chesley MM, Minor TB (1996) Groundwater assessment using remote sensing and GIS in a rural groundwater project in Ghana: lessons learned. Hydrogeol J 4(3):40-49

Saaty TL (1980) The analytic hierarchy process: planning, priority setting, resource allocation. McGraw Hill, New York

Saaty TL (1999). Fundamental of analytic network process. In International Symposium of the Analytic Hierarchy Process (ISAHP), Kobe, Japan.

Shekhar S, Pandey AC (2014) Delineation of groundwater potential zone in hard rock terrain of Indiausing remote sensing, geographical information system (GIS) and analytic hierarchy process (AHP) techniques. Geocarto Int 30(4):402-421. https://doi.org/10. 1080/10106049.2014.894584

Singh PK, Bhardwaj OA, Kumar A (2011) Site selection for groundwater recharge zone in municipal wastewaters a case study of Varanasi (India). Recent Adv Civil Eng Conserv 10(2):98-103

Srivastava PK, Bhattacharya AK (2006) Groundwater assessment through an integrated approach using remote sensing, GIS and resistivity techniques: a case study from a hard rock terrain. Int J Remote Sens 27(20):4599-4620

Thapa R, Gupta S, Guin S, Kaur H (2017) Assessment of groundwater potential zones using multi-influencing factor (MIF) and GIS: a case study from Birbhum district, West Bengal. Appl Water Sci 7:4117-4131. https://doi.org/10.1007/s13201-017-0571-z

Publisher's Note Springer Nature remains neutral with regard to jurisdictional claims in published maps and institutional affiliations. 